P-ISSN: 2615-1723

E-ISSN: 2615-1766

Oktober 2018
Jurnal Riset Pendidikan Dasar 01 ( 2), ( 2018) 101-106

Submitted: Agustus, Accepted: September, Published: Oktober

\title{
EFEKTIFITAS MODEL CREATIVE PROBLEM SOLVING DENGAN MEDIA TEKA-TEKI SILANG DAUN TERHADAP AKTIVITAS DAN HASIL BELAJAR IPA SEKOLAH DASAR
}

\author{
Erwin Putera Permana \\ Program Studi Pendidikan Guru Sekolah Dasar, Fakultas Keguruan dan Ilmu Pendidikan \\ Universitas Nusantara PGRI Kediri, Indonesia
}

Korespondensi. E-mail: erwinpermana87@gmail.com

\begin{abstract}
Abstrak
Berdasarkan hasil temuan observasi bahwa siswa kesulitan dalam menerima materi pelajaran, khususnya pembelajaran IPA (Ilmu Pengetahuan Alam). Hal ini dikarenakan kegiatan belajar mengajar tanpa adanya media maupun model pembelajaran, permasalahan ini mengakibatkan kebosanan dan membuat siswa malas untuk belajar. Dengan adanya penelitian ini diharapkan aktivitas serta hasil belajar meningkat pada siswa. Penelitian ini mengaplikasikan pendekatan kuantitatif dengan subyek penelitian siswa Sekolah Dasar kelas IV. Penelitian ini terlaksana dalam tiga kali pertemuan, menggunakan instrumen RPP, postest, lembar observasi aktivitas siswa, dan lembar observasi aktivitas guru. Kesimpulan hasil penelitian ini adalah penerapan Model CPS dengan Media Teka-Teki Silang Daun terhadap aktivitas pembelajaran IPA pokok bahasan jenis-jenis daun memperoleh rerata 82,3\% sehingga masuk kategori aktif. Penerapan Model CPS dengan Media Teka-Teki Silang Daun terhadap hasil belajar pada pembelajaran IPA pokok bahasan jenis-jenis daun memperoleh rerata 87,32\% sehingga masuk kategori sangat baik. Aktivitas belajar siswa menggunakan Model CPS dan Media Teka-Teki Silang Daun lebih baik daripada hasil belajar siswa menggunakan Model CPS tanpa menggunakan Media Teka-Teki Silang Daun. Hasil belajar menggunakan Model CPS dan Media Teka-Teki Silang Daun pada siswa lebih baik daripada hasil belajar menggunakan Model Creative Problem Solving tanpa menggunakan Media Teka-Teki Silang Daun.
\end{abstract}

Kata Kunci: Model Creative Problem Solving, Media Teka-teki Silang Daun, Aktivitas, Hasil Belajar.

\section{THE EFFECTIVENESS OF CREATIVE PROBLEM SOLVING MODELS WITH LEAF CROSS CROSSES MEDIA ON THE ACTIVITIES AND LEARNING OUTCOMES OF ELEMENTARY SCHOOL SCIENCE}

\begin{abstract}
Based on the observation findings that students have difficulty in receiving the subject matter, especially science learning (Natural Sciences). This is because teaching and learning activities without media or learning models, these problems lead to boredom and make students lazy to learn. With the existence of this research, it is expected that activities and learning outcomes will increase in students. This study applies a quantitative approach to the research subjects of grade IV elementary school students. This study was carried out in three meetings, using RPP instruments, posttest, student activity observation sheets, and teacher activity observation sheets. The conclusion of the results of this study is the application of the CPS Model with the Leaf Crossing Media to the science learning activities of the subject types of leaves gained an average of $82.3 \%$ so that it was in the active category. The application of the CPS Model with the Leaf Crossing Media to the learning outcomes of natural science learning the subject of leaf types gained an average of $87.32 \%$ so that it was in the very good category. Student learning activities using the CPS Model and Leaf Cross Crosses Media are better than student learning outcomes using the CPS Model without using the Leaf Cross Crosses Media. Learning outcomes using the CPS Model and Leaf Cross Crossword Media on students were better than the learning outcomes using Creative Problem Solving Model without using Leaf Cross Crosses Media.
\end{abstract}

Keywords: Creative Problem Solving Models, Leaf Cross Crosses Media, Activities, Learning Outcomes.

Copyright C2018, JRPD, ISSN 2615 - 1723 (Print), ISSN 2615 - 1766 (Online) 


\section{Jurnal Riset Pendidikan Dasar, 01 (2), Oktober 2018 (101-106)}

Erwin Putera Permana

\section{PENDAHULUAN}

Pembelajaran adalah proses yang dilakukan untuk penyampaian ilmu pengetahuan, yang dilakukan dengan menyampaikan pengetahuan kepada siswa (Permana, 2017). Bila pembelajaran dinilai sebagai suatu proses, maka pembelajaran adalah serangkaian cara atau kegiatan guru untuk membuat siswa belajar. Salah satu pengertian pembelajararan dikemukakan juga oleh (Gagné R, 1970) yaitu pembelajaran adalah seperangkat peristiwa-peristiwa eksternal yang dirancang untuk mendukung beberapa proses belajar yang bersifat internal. Lebih lanjut, (Gagne, 1972) menyampaikan teorinya secara lengkap dengan menyatakan bahwa pembelajaran bertujuan untuk memperoleh hasil belajar, situasi ini diciptakan sedemikian rupa untuk mendukung, mengaktifkan, dan mempertahankan proses berpikir yang terdapat dalam setiap kegiatan belajar.

Berdasarkan pada pendapat beberapa ahli tersebut maka dapat disimpulkan bahwa pembelajaran merupakan suatu rangkaian dan proses tindakan yang dilakukan guru dalam rangka menciptakan iklim belajar siswa, pembelajaran juga merupakan persiapan di masa mendatang dan sekolah mempersiapkan mereka untuk kembali ke masyarakat sutu hari nanti. (Permana, 2017) IPA (Ilmu Pengetahuan Alam) adalah salah satu mata pelajaran di SD (Sekolah Dasar) yang bertujuan agar siswa memiliki pengetahuan, konsep dan gagasan yang terorganisir mengenai alam sekitar, yang didapatkan dari pengalaman melalui tahapan-tahapan ilmiah antara lain penyusunan, penyelidikan dan penyajian ide-ide.

IPA merupakan pengetahuan khusus yaitu dengan melakukan eksperimentasi, observasi, penyusunan teori, menarik kesimpulan dan demikian seterusnya saling berhubungan antara cara yang satu dengan cara yang lain. IPA berhubungan dengan proses inkuiri yang berhubungan dengan alam secara sistematis, sehingga IPA tidak hanya tentang penguasaan kumpulan sistematis dan IPA tidak hanya penguasaan kumpulan pengetahuan yang berupa fakta, konsep atau prinsip saja, tetapi juga proses mencari tahu atau inkuiri. (Sri Sulistyorini, 2015).

(Bloom, 2001) menjelaskan bahwa iklim belajar yaitu pengaruh, kondisi, dan rangsangan eksternal yang meliputi pengaruh sosial, fisik, dan pemikiran yang mempengaruhi siswa. Selain itu, (Ryan \& Miskell, 2016) menjelaskan tentang iklim belajar merupakan kualitas dari lingkungan (kelas) yang secara kontinu dialami oleh pengajar, mempengaruhi tingkah laku, dan berdasarkan pada persepsi kolektif tingkah laku mereka. Selanjutnya, istilah iklim seperti kepribadian pada manusia. Artinya, setiap kelas mempunyai ciri (kepribadian) yang tidak sama dengan kelas-kelas yang lain, meskipun kelas itu dibangun dengan bentuk, fisik maupun desain yang sama. Iklim kelas seperti halnya manusia, ada yang sangat berbasis pada tugas, demokrasi, formal, terbuka, maupun tertutup.

Untuk mewujudkan proses pembelajaran dan iklim belajar yang kondusif pada peserta didik, hal ini tidak terlepas dari peran seorang guru. Guru merupakan salah satu faktor utama dalam meningkatkan kualitas pembelajaran, disamping faktor lain diantaranya: siswa, kurikulum, sarana dan prasarana untuk pembelajaran tetapi juga manajemen berbasis sekolah yang menyeluruh (Permana \& Imron, 2016). Oleh karena itu, guru harus memiliki kemampuan dasar yang mengumpuni, antara lain mampu menguasai materi, dapat menyampaikan materi dengan model dan metode pembelajaran yang tepat, mengelola kelas, dan menggunakan alat peraga yang mendukung untuk penyampaian materi.

Selain itu, untuk memperoleh kualitas pembelajaran yg baik juga di tinjau dari aktivitas belajar siswa. aktivitas belajar dalam pembelajaran dapat dilihat dari keaktifan siswa ketika mencoba mengerjakan dan menyelesaikan latihan soal baik individu

Copyright $@ 2018$, JRPD, ISSN 2615 - 1723 (Print), ISSN 2615 - 1766 (Online) 
maupun kelompok. Kemampuan siswa dalam mengkomunikasikan hasil pikiran dan penemuan secara lisan, yaitu dengan mengajukan pertanyaan kepada guru atau siswa lain, menyajikan hasil pekerjaan, serta menanggapi hasil pekerjaan siswa lain. Tetapi pada kenyataan di lapangan bahwa, kegiatan belajar mengajar IPA dirasa masih kurang aktif dan terkesan membosankan bagi siswa, dimana guru hanya mengajar dengan memberikan materi kemudian siswa mendengarkan dan mencatat materi yang dipelajari, serta cenderung terfokus pada materi yang ada pada buku teks. Hal ini membuat siswa cenderung malas belajar dan membuat rasa ketertarikan siswa terhadap IPA berkurang.

Proses belajar mengajar menjadi tidak kondusif karena banyak siswa yang ramai dan tidak memperhatikan apa yang dijelaskan guru. Keadaan tersebut berpengaruh terhadap aktivitas belajar siswa yang cenderung pasif dan hasil belajar mereka yang rendah. Hal ini dibuktikan dari hasil belajar siswa pada ulangan harian peserta didik di kelas IV SD Kota Kediri sebelum dilaksanakan penelitian. Dari data yang diperoleh berdasarkan hasil ulangan IPA siswa yaitu 94.02\% mendapatkan nilai berada di bawah KKM (diambil dari data semester 1 pada tahun ajaran 2017). Berkaitan dengan permasalahan yang ada pada pembelajaran, maka perlu dicari solusi pemecahannya. Solusinya adalah menciptakan pembelajaran yang inovatif, salah satunya adalah penerapan model dan media. (Wulandari, 2015) Di antara berbagai model pembelajaran, model Creative Problem Solving dengan mengaplikasikan media Teka-teki silang daun yang tepat sasaran jika diterapkan dalam penelitian ini untuk mampu meningkatkan aktivitas dan hasil belajar siswa.

\section{METODE}

Variabel yang diaplikasikan pada penelitian ini dapat diklasifikasikan menjadi dua yaitu variabel bebas dan varabel terikat.
Variabel bebas (independen) dalam penelitian ini adalah Model Creative Problem Solving dan Media Teka-teki Silang Daun. Variabel terikat (dependen) dalam penelitian ini adalah aktivitas dan hasil belajar siswa. Pendekatan yang digunakan dalam penelitian ini adalah pendekatan kuantitatif. (Permana \& Sari, 2018) Alasan menggunakan pendekatan kuantitatif adalah untuk memperoleh data berupa angka. Data diperoleh melalui hasil akhir yaitu berupa hasil tes yang dilakukan di akhir pembelajaran (Post test) sehingga penarikan kesimpulan dapat dilakukan dengan tepat. Penelitian ini dilakukan di Sekolah Dasar di Kota Kediri dan Peneliti akan melaksanakan penelitian pada tahun pelajaran 2017/2018. Penelitian dilaksanakan selama dua minggu, tanggal 02 Agustus - 16 Agustus 2017.

Populasi dalam penelitian ini adalah semua siswa kelas IV SD di Kota Kediri. Sampel penelitian menggunakan jenis sampel yang digunakan adalah random sampling. Dari sekina banyak sekolah dasar di Kota kediri hanya di ambil 2 kelas secara acak untuk 1 kelas kontrol dan 1 kelas eksperimen. Instrumen yang digunakan dalam penelitian ini berupa Program Tahunan, Program Semester, Silabus, RPP (Rencana Pelaksanaan Pembelajaran), Post test, Lembar Aktivitas Guru, dan Lembar Aktivitas Siswa. Sebelum instrumen digunakan, terlebih dahulu diadakan validasi instrumen. Validator terdiri dari satu orang dosen pengampu mata kuliah Perencanaan Pembelajaran Sekolah Dasar lulusan S2 Pendidikan Dasar konsentrasi Guru Kelas dan satu orang guru yaitu guru kelas IV Sekolah Dasar di Kota Kediri dengan pendidikan S1 PGSD.

\section{HASIL DAN PEMBAHASAN}

Sebelum melaksanakan penelitian terlebih dahulu peneliti memvalidasikan instrumen penelitian ke validator, yaitu dosen Pendidikan Guru Sekolah Dasar dan guru SD.

Copyright $@ 2018$, JRPD, ISSN 2615 - 1723 (Print), ISSN 2615 - 1766 (Online) 
Dari hasil validasi diperoleh rata-rata hasil yaitu silabus sebesar 87,91 , posttest sebesar 78,34, lembar aktivitas guru sebesar 85,58, lembar aktivitas siswa sebesar 86,54, dan RPP sebesar 75,83 . Dari hasil yang divalidasikan diperoleh bahwa instrumen penelitian valid untuk di uji cobakan sesuai dengan kriteria yang ditetapkan. Setelah instrumen yang di validasi mendapat hasil yang valid untuk di uji cobakan, peneliti melakukan uji validitas dan reliabelitias instrumen tes. Adapun hasil dari uji validitas dan uji reliabilitas yang di bantu program SPSS 21 adalah sebagai berikut.

Tabel 1. Hasil Analisis Validitas Soal Uji Coba

\begin{tabular}{lccccc}
\hline Data & No Soal & Jumlah & Kriteria & $\begin{array}{c}\text { Prosentase } \\
(\mathbf{\%})\end{array}$ & Data \\
\hline Postest $1 \mathrm{a}, 1 \mathrm{~b}, 2 \mathrm{a}, 2 \mathrm{~b}, 3,4,5$ & 7 & Valid & 100 & Postest \\
\hline
\end{tabular}

Tabel 2. Hasil Analisis Reliabilitas Soal Uji Coba

\begin{tabular}{ccc}
\hline Data & Alpha & Keterangan \\
\hline Postest & 0,774 & Reliabel \\
\hline
\end{tabular}

Berdasarkan pada table 1 dan 2 di atas, menunjukkan instrumen tes valid dan reliable. Sehingga, soal pretest dan posttest dapat di uji cobakan. Selanjutnya, dari penjelasan di atas yang sudah sesuai dengan kriteria yang diinginkan maka peneliti terjun ke lapangan untuk melaksanakan penelitian. Adapun hasil yang diperoleh adalah sebagai berikut.
Hasil belajar siswa atau posttest diperoleh $76 \%$ siswa masuk kategori sangat baik, 24\% siswa masuk kategori baik, dan $0 \%$ pada kategori lainnya. Setelah mendapat hasil posttest peneliti penguji normalitas dan homogenitas yang bertujuan untuk syarat melakukan uji hipotesis. Hasil dari uji normalitas dan homogenitas yaitu :

Tabel 3. Hasil Analisis Uji Normalitas

One-Sample Kolmogorov-Smirnov Test

\begin{tabular}{|c|c|}
\hline & EKSPERIMEN \\
\hline $\begin{array}{ll}\text { N } & \text { Mean } \\
\text { Normal Parameters }{ }^{\mathrm{a}, \mathrm{b}} & \begin{array}{l}\text { Std. } \\
\text { Deviation } \\
\\
\text { Absolute }\end{array} \\
\text { Most Extreme Differences Positive } \\
\text { Negative } \\
\text { Kolmogorov-Smirnov } \\
\text { Z Asymp. Sig. (2- } \\
\text { tailed) }\end{array}$ & $\begin{array}{r}25 \\
82,30 \\
5,293 \\
\\
, 123 \\
, 123 \\
-, 067 \\
, 613 \\
, 847\end{array}$ \\
\hline
\end{tabular}

a. Test distribution is Normal. b. Calculated from data.

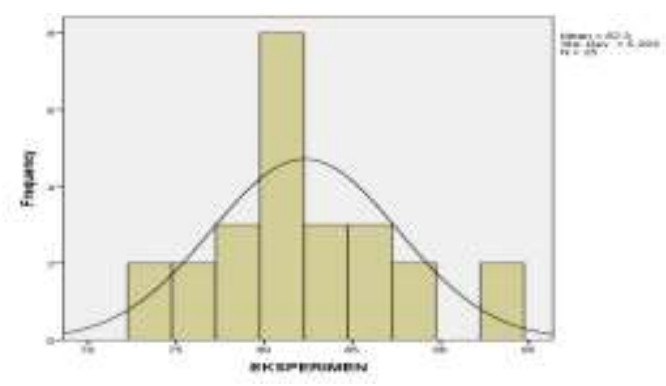

Gambar 1. Grafik Uji Normalitas SPSS 21

Copyright $\odot 2018$, JRPD, ISSN 2615 - 1723 (Print), ISSN 2615 - 1766 (Online) 
Berdasarkan hasil tabel dan grafik di atas menujukkan nilai sig 0,847. Hal ini menunjukkan nilai sig $>0,05$ sehingga data berdistribusi normal. Adapun dalam uji homogenitas diperoleh :

Tabel 4. Hasil Analisis Uji Homogenitas

Test of Homogeneity of Variances

\begin{tabular}{|c|c|c|c|}
\hline Levene & df1 & df2 & Sig. \\
\hline, 001 & 1 & 48 &, 971 \\
\hline
\end{tabular}

Berdasarkan table 4 di atas terlihat nilai sig data pretest dari kelas eksperimen dan kelas kontrol adalah 0,971. Hal ini menunjukkan nilai sig lebih dari 0,05 . Dengan demikian diperoleh keputusan kemampuan pemecahan masalah siswa dari data pretest homogen. Hal ini menunjukkan kelas eksperimen dan kelas kontrol mempunyai varian yang sama.

Hasil Observasi Aktivitas Siswa yang dilaksanakan selama dua pertemuan diperoleh hasil $82,3 \%$ siswa aktif dalam melaksanakan pembelajaran. Dari hasil penelitian yang telah dilakukan, peneliti melakukan uji hipotesis dengan menggunakan uji Independent Sample $t$ test menggunakan bantuan SPSS 21. Adapun hasil dari uji hipotesis tersebut adalah Hasil analisis data aktivitas siswa dalam model Creative Problem Solving diperoleh hasil Sig. (2-tailed) adalah 0,000 sehingga Sig. (2- tailed) kurang dari 0,05. Dengan demikian demikian Aktivitas belajar siswa menggunakan model Creative Problem Solving dengan Media Tekateki Silang Daun lebih baik dari pada menggunakan model Creative Problem Solving tanpa Media Teka-teki Silang Daun. Hasil analisis uji hipotesis hasil belajar siswa diperoleh nilai Sig. (2-tailed) adalah 0,000 sehingga Sig. (2-tailed) kurang dari 0,05. Dengan demikian hasil belajar siswa menggunakan model Creative Problem Solving dengan Media Teka-teki Silang Daun lebih baik daripada menggunakan model Creative Problem Solving tanpa Media Teka-teki Silang Daun. Dari hasil uji hipotesis di atas menunjukkan bahwa tujuan penelitian ini tercapai.

\section{SIMPULAN}

Berdasarkan hasil penelitian beserta analisisnya dapat disimpulkan bahwa aktivitas dalam belajar siswa menggunakan Model CPS (Creative Problem Solving) dengan Media Teka-Teki Silang Daun pada mata pelajaran IPA dengan materi jenis-jenis daun berjalan dengan baik. Hal ini dapat dilihat dari rerata jumlah hasil dari dua pertemuan Model Creative Problem Solving dengan Media Tekateki Silang Daun yaitu mencapai 82,3\% dalam kategori baik.

Hasil belajar siswa dalam pembelajaran menggunakan Model Creative Problem Solving dengan Media Teka-Teki Silang Daun pada pembelajaran IPA materi jenis daun memperoleh hasil yang sangat baik. Hal ini terlihat dari hasil post test Model Creative Problem Solving dengan Media Teka-Teki Silang Daun yaitu mendapatkan nilai rata-rata kelas sebesar 87,32\% dalam kategori sangat baik.

Aktivitas belajar siswa yang dilakukan pembelajaran menggunakan Model Creative Problem Solving dengan Media Teka-Teki Silang Daun lebih baik daripada aktivitas belajar siswa yang diajar menggunakan Model Creative Problem Solving tanpa menggunakan Media Teka-Teki Silang Daun. Hal ini ditunjukkan dari hasil analisis data aktivitas siswa diperoleh rerata kelas sebesar $82,3 \%$ yang masuk pada kategori aktif. Sedangkan, 
hasil analisis data aktivitas siswa diperoleh rerata kelas sebesar $75,86 \%$ yang masuk pada kategori cukup aktif.

Selain itu uji t-tes (Analisis Uji Independent sample test) menggunakan SPSS 21 memperoleh nilai sig (2-tailed) yaitu 0,000. Dengan demikian Ha diterima dan Ho ditolak yang berarti hasil belajar siswa menggunakan Model Creative Problem Solving dengan Media Teka-Teki Silang Daun lebih baik dari pada menggunakan Model Creative Problem Solving tanpa Media Teka-Teki Silang Daun. Dari hasil analisis data aktivitas siswa tersebut, maka dapat disimpulkan bahwa aktivitas belajar siswa yang diajar menggunakan Model Creative Problem Solving dengan media Teka-teki Silang Daun lebih baik daripada hasil belajar siswa yang diajar menggunakan Model Creative Problem Solving tanpa menggunakan media Teka-Teki Silang Daun pada materi Jenis-jenis daun di SD Kota Kediri.

Hasil belajar siswa yang diajar menggunakan Model Creative Problem Solving dengan Media Teka-Teki Silang Daun lebih baik daripada hasil belajar siswa yang diajar menggunakan Model Creative Problem Solving tanpa menggunakan Media Teka-Teki Silang Daun. Hal ini terlihat dari hasil penelitian dan pembahasan yang menyatakan bahwa nilai sig (1-tiled) $=0,000<0,05$, maka Ho ditolak. Artinya rata-rata hasil belajar kelas eksperimen lebih baik daripada kelas kontrol. Maka dapat disimpulkan bahwa, hasil belajar siswa menggunakan Model Creative Problem Solving dengan Media Teka-teki Silang Daun lebih baik dari pada menggunakan Model Creative Problem Solving tanpa Media Teka-teki Silang Daun.

\section{DAFTAR PUSTAKA}

Bloom, B. (2001). Bloom 's Taxonomy. ReVision, 1-6.

Gagne, R. (1972). Learning and individual differences. Learning and individual differences.
Gagné R. (1970). The conditions of learning. Science, 1(34), 1993. https://doi.org/10.1016/00224405(79)90058-X

Permana, E. P., \& Imron, I. F. (2016). Penerapan PEMBELAJARAN IPS dengan Media Ular Tangga untuk Meningkatkan Minat Belajar Siswa Kelas IV SDN Kecamatan Prambon Nganjuk. EFEKTOR, 1(28), 67-70.

Permana, E. P., \& Nourmavita, D. (2017). Pengembangan Multimedia Interaktif Pada Mata Pelajaran IPA Materi Mendeskripsikan Daur Hidup Hewan Di Lingkungan Sekitar Siswa Kelas IV Sekolah Dasar. Jurnal PGSD, 10(2), 7985.

Permana, E. P., \& Sari, Y. E. P. (2018). Development of Pop Up Book Media Material Distinguishing Characteristics of Healthy and Unfit Environments Class III Students Elementary School. International Journal of Elementary Education, 2(1), 8-14. Retrieved from https://ejournal.undiksha.ac.id/index.p $\mathrm{hp} / \mathrm{IJEE}$

Richa Safitri Wulandari. (2015). Artikel Skripsi Universitas Nusantara PGRI Kediri. Efektifitas Model Pembelajaran CPS (Creative Problem Solving) dengan Media Adobe Flash Terhadap Aktivitas dan Hasil Belajar Siswa pada Pembelajaran Matematika Pokok Bahasan Logaritma Kelas X SMA Pawyatan Daha Kediri, 1(1), 1-16.

Ryan, M., \& Miskell, S. (2016). Implementing model-based design for flight critical applications. In American Helicopter Society International - Specialists' Meeting on Development, Affordability and Qualification of Complex Systems 2016 (pp. 40-53).

Sri Sulistyorini, Hardjono, Harmanto, A. E. A. (2015). Pelatihan Pengembangan Penilaian Otentik dan Penulisan Rapor SD Kurikulum 2013 bagi Guru-guru SD Dinas Pendidikan Kecamatan Gayamsari Kota Semarang. ABDIMAS, 19(1), 57-62. 